\title{
ДОТРИМАННЯ ПРАВ ЛЮДИНИ ПРИ ОСКАРЖЕННІ СУДОВИХ РІШЕНЬ У КРИМІНАЛЬНИХ ПРОВАДЖЕННЯХ У ПРАКТИЦІ ЄВРОПЕЙСЬКОГО СУДУ З ПРАВ ЛЮДИНИ
}

\author{
Качалко К. П., Плужнік О. І.
}

\begin{abstract}
у статті висвітлено окремі питання регламентаціі права на оскарження судових рішень у кримінальних провадженнях, гарантованого Конвенцією про захист прав людини та основоположних свобод 1950 року, а також проаналізовано прецедентну практику Європейського суду з прав людини та Комітету з прав людини ООН у цій сфері. Механізм реалізації права на оскарження досліджено в умовах реформування національної системи судоустрою. Проаналізовано колізійний вплив принципів правової визначеноcmi ma res judicata, з одного боку, та права на ефективний судовий захист, з іншого боку, на формування системи оскарження та перегляду рішень судів в Україні.

Ключові слова: право на оскарження, оскарження, судові рішення, практика ЄСПЛ, практика КПЛ ООН, апеляційне оскарження, обмеження права на оскарження, міжнародний стандарт оскарження.
\end{abstract}

В статье освещены отдельные вопросы регламентации права на обжалование судебных решений по уголовным производствам, гарантированного Конвенцией о защите прав человека и основных свобод 1950 года, а также проанализирована судебная практика Европейского суда по правам человека и Комитета по правам человека ООН в этой сфере. Механизм реализации права на обжалование исследован в условиях реформирования национальной системы судоустройства. Проанализировано коллизионное влияние принципов правовой определенности и res judiсата, с одной стороны, и права на эффективную судебную защиту, с другой стороны, на формирование системы обжалования и пересмотра решений судов в Украине.

Ключевые слова: право на обжалование, обжалование, судебные решения, практика ЕСПЧ, практика КПЧ ООН, апелляционное обжалование, ограничения права на обжалование, международный стандарт обжалования.

The article examines the international standards of the right of appeal filed by international bodies that monitor compliance with international legal instruments - the European Court of Human Rights (ECHR) and the UN Human Rights Committee.

The article describes the permissible limits of the right to appeal. It has been determined that national European legal systems for the defense side allow for such restrictions to the right of appeal as: the appeal of certain court decisions in criminal cases only on legal grounds and the prohibition on appeal on the basis of actual grounds; the existence of a procedure for obtaining the consent of the court to an appeal, in which a person who wishes to appeal a criminal conviction must apply for a permit to file an appeal; exclusion from the right to appeal, when the person was convicted in the first instance by the Supreme Court or convicted of the outcome of the appeal.

Some issues of the regulation of the right to appeal judicial decisions in criminal proceedings guaranteed by the 1950 Convention on the Protection of Human Rights and Fundamental

Качалко К. П., Плужнік О. І., 2019
Freedoms are also covered, as well as the case law of the European Court of Human Rights and the UN Human Rights Committee in this area. The mechanism for realizing the right to appeal was investigated in the context of reforming the national system of judicial system. The collisional influence of the principles of legal certainty and res judicata, on the one hand, and the right to effective judicial protection, on the other, on the formation of a system of appeal and review of court decisions in Ukraine is analyzed.

In accordance with international standards of the right to appeal judicial decisions in criminal cases, only the convicted person has an unconditional right to appeal. The content and limits of the right to appeal judicial decisions in criminal matters of other participants in criminal proceedings, including the victim, are determined by national legislation and are not part of these standards.

Key words: the right to appeal, appeal, judgements, ECHR practice, practice of the UN Human Rights Commission, appellate, limit the right of appeal, the international standard for appeal.

Постановка проблеми та іï актуальність. Право на оскарження судових рішень у кримінальних провадженнях $€$ одним з фундаментальних прав учасників кримінального судочинства, яке гарантує винесення справедливого рішення. Дане право закріплене в найбільш значущих міжнародних правових актах. Зокрема, п. 5 ст. 14 Міжнародного пакту про громадянські і політичні права 1966 р. проголошує, що кожен, кого засуджено за будь-який злочин, має право на те, щоб його засудження і вирок були переглянуті вищою судовою інстанцією згідно з законом.

У системі правових актів Ради Європи право на оскарження судових рішень закріплене в ст. 2 «Право на оскарження в кримінальних справах» Протоколу № 7 до Конвенції про захист прав людини і основних свобод 1950 р.: «Кожен, хто засуджений за вчинення кримінального правопорушення, має право на те, щоб винесений відносно нього вирок або покарання були переглянуті вищою судовою інстанцією. Здійснення цього права, а також підстави, на яких воно може бути здійснене, регулюються законом».

У зв' язку із активним процесом реформування судової системи України особливий інтерес становить вивчення міжнародних стандартів права на оскарження, вироблених міжнародними органами, що здійснюють контроль за дотриманням вищевказаних міжнародних правових актів, тобто Європейським Судом з прав людини (ЄСПЛ) і Комітетом 3 прав людини ООН (КПЛ ООН).

Необхідно відзначити, що безпосередньо питання обмеження права на оскарження судових рішень у кримінальних справах були предметом розгляду ЄСПЛ дуже рідко. ЄСПЛ, як правило, розглядає свободу оскарження 
не як окреме право особи, яка діє виключно в рамках кримінальної юрисдикції, а як складову частину більш широкого права на справедливий судовий розгляд. Під час виявлення допущеного порушення ст. 6 Конвенції («Право на справедливий судовий розгляд») ЄСПЛ не вважає за необхідне окремо розглядати також питання про те, чи сталося порушення ст. 2 Протоколу № 7 до Конвенції, яка закріплює право кожного на оскарження.

Метою дослідження $\epsilon$ науковий аналіз проблеми дотримання прав людини при оскарженні судових рішень у кримінальних провадженнях у практиці Європейського суду з прав людини.

Виклад основного матеріалу. У практиці КПл ООН недотримання п. 5 ст. 14 Міжнародного пакту про громадянські і політичні права утворює самостійне порушення.

Як правило, рішення, в яких ЄСПЛ доходив висновку про порушення безпосередньо ст. 2 Протоколу № 7 до Конвенції, яка закріплює право кожного на оскарження, належали не до кримінальних справ в розумінні національного законодавця, а до адміністративних. Дана обставина зумовлена різним розумінням видів кримінально караних діянь. Так, кримінальне законодавство Франції містить поділ кримінально караних діянь на три таких види: кримінальні правопорушення, кримінальні проступки та кримінальні злочини. До злочинів в розумінні національного законодавця із зазначених видів в повній мірі належать кримінальні злочини і частково кримінальні проступки. Таким чином, діяння, віднесені українським законодавством до адміністративних правопорушень, в деяких країнах класифікуються як кримінально карані [1].

Поширення статті 2 Протоколу № 7 до Конвенції про захист прав людини на адміністративні правопорушення ЄСПЛ у своїх рішеннях ставить в залежність від можливого покарання. Зокрема, якщо можливе покарання у справі про адміністративне правопорушення передбачає позбавлення волі (адміністративний арешт), то ЄСПЛ вважає, що дане діяння не тільки має кримінально-правовий характер і на нього поширюються всі гарантії статті 6 Конвенції та статті 2 Протоколу № 7 до неї, але також таке покарання не може бути визнане малозначним. Отже, положення частини 2 статті 2 Протоколу № 7 в даних випадках не застосовуються. Навіть в тому випадку, якщо у справі було призначене покарання, не пов'язане з позбавленням волі, але відповідна стаття кримінального або адміністративного законодавства передбачає можливість його застосування, застереження частини 2 статті 2 Протоколу № 7 також не підлягає застосуванню [2].

Аналогічної точки зору ЄСПЛ дотримується і щодо правопорушень, які відповідно до національних законодавств мають дисциплінарний характер і застосовуються щодо окремих категорій громадян, наприклад, засуджених або військовослужбовців.

Оскільки п. 5 ст. 14 Міжнародного пакту про громадянські і політичні права не містить застереження про малозначність покарання стосовно можливості апеляції, то позиція КПЛ ООН з даного питання $\epsilon$ не менш важливою. Відповідно до точки зору, виробленої КПЛ $\mathrm{OOH}$, враховуючи різні варіанти передачі слова «злочин» різними мовами (crime, infraction, delito), зазначимо, що дана гарантія діє не тільки в разі найбільш серйозних правопорушень [3].
Отже, вважаємо за необхідне виділити основні критерії змісту і меж права на оскарження судових рішень у кримінальних справах, відображені в рішеннях і інших документах ЄСПЛ і КПЛ ООН.

Найбільш важливими з таких критеріїв, на нашу думку, є допустимі обмеження права на оскарження. Національні європейські правові системи для сторони захисту допускають такі обмеження права на оскарження:

- оскарження деяких судових рішень у кримінальних справах лише з правових підстав і заборону на оскарження на фактичних підставах. Наприклад, у ФРН вироки, винесені палатами Земельного суду, а також Вищим земельним судом, апеляційному оскарженню не підлягають і можуть бути оскаржені лише з правових підстав в касаційному порядку (ст. 333 КПК ФРН) [4];

- наявність процедури отримання згоди суду на оскарження, при якій особа, яка бажає подати апеляцію на обвинувальний вирок у кримінальній справі, має клопотати про дозвіл на подачу апеляції. Наприклад, в Англії така згода необхідна при оскарженні вироку Суду Корони в Апеляційному Суді. Апелянтові необхідно представити мотиви своєї апеляції та підтвердити докази у суді першої або апеляційної інстанції, який після консультацій з іншою стороною приймає рішення з даного клопотання. Право на повний розгляд своєї апеляції заявник отримує після отримання дозволу;

- виключення з права на оскарження, що випливають 3 положень ч. 2 ст. 2 Протоколу № 7 до Європейської конвенції про захист прав людини, коли особу було засуджено у першій інстанції Верховним судом або засуджено за результатами розгляду апеляції [5].

У своїх рішеннях ЄСПЛ неодноразово вказував, що державам-учасницям Конвенції про захист прав людини і основних свобод надана широка свобода розсуду при визначенні того, як право оскарження буде здійснюватися. Відповідно до Конвенції державам надається можливість обмежувати право оскарження декількома способами: в одних випадках право оскарження може обмежуватися тільки питаннями права, в інших випадках особа, яка бажає звернутися до вищого суду, має отримати дозвіл на апеляцію.

Дана точка зору закріплює наявні обмеження в праві на оскарження в законодавстві європейських національних систем і має прецедентний характер для рішень ЄСПЛ.

Комітет з прав людини ООН у своїй практиці частково дотримується іншої точки зору на допустимість подібних обмежень. Відносно першого обмеження, пов'язаного із забороною на оскарження окремих судових рішень у кримінальних справах за фактичними підставами, КПЛ ООН вважає, що встановлюється пунктом 5 статті 14 Міжнародного пакту про громадянські і політичні права право на перегляд засудження і вироку судом вищої інстанції, що накладає на державу-учасницю обов'язок перегляду істотно й одночасно фактів на основі достатності доказів і норм права. Перегляд, який обмежується формальними або правовими аспектами засудження без будь-якого розгляду фактів, $\epsilon$ недостатнім (п. 48 Зауважень загального порядку № 32 КПЛ ООН).

На підтвердження даної позиції в рішенні у справі «Х.Г. Мартінес проти Іспанії» КПЛ ООН встановив порушення права на оскарження при касаційному розгляді 
справи у Верховному суді, яке виразилося в тому, що відносно засудженого був винесений обвинувальний вердикт, що стосувався доказів, представлених стороною обвинувачення, які не були піддані повноцінному розгляду вищим судом. Аналогічна точка зору наводиться і в інших рішеннях КПЛ ООН [6].

Отже, КПЛ ООН негативно ставиться до наявної практики законодавчого обмеження права на оскарження деяких судових рішень у кримінальних справах тільки юридичними підставами.

У тих випадках, коли судова інстанція, яка зобов'язана проводити перегляд справи тільки з юридичних підстав, фактично виходить за рамки, передбачені для неї національним законодавствам, і досліджує фактичні питання, КПЛ ООН встановлює відсутність порушення Пакту.

Що стосується другого розглянутого нами обмеження - необхідності отримання згоди на подачу апеляційної скарги, то практика КПл ООН не така однозначна. Зокрема, в рішенні у справі «Томас Меннен проти Нідерландів», в якій той оскаржив рішення судді апеляційного суду Гааги, який постановив, що питання про апеляцію не розглядатиметься, оскільки інтереси належного здійснення правосуддя не вимагають розгляду цієї справи в апеляційному порядку, КПЛ ООН визнав порушення п. 5 ст. 14 Пакту. Комітет зазначив, що вважає таку мотивацію неадекватною і недостатньою. При прийнятті рішень про розгляд справ в апеляційному порядку питання про такий перегляд має розглядатися по суті з урахуванням, з одного боку, доказів, наданих суду першої інстанції, а $з$ іншого - судового розгляду на підставі юридичних положень, які можна застосувати до конкретної справи [7].

У практиці КПЛ ООН подібні рішення трапляються неодноразово.

Міжнародний пакт про громадянські і політичні права, на відміну від Європейської конвенції про захист прав людини і основних свобод, не містить застереження про те, що з права на оскарження може бути зроблений виняток, коли особа була засуджена у першій інстанції Верховним судом або засуджена після оскарження виправдувального вироку.

У зв'язку з цим КПЛ ООН сприймає цю ситуацію як порушення п. 5 ст. 14 Пакту (п. 47 Зауважень загального порядку № $32 \mathrm{KПЛ} \mathrm{ООН).} \mathrm{Так,} \mathrm{у} \mathrm{справі} \mathrm{«Х.} \mathrm{Серена}$ i К. Родрігес проти Іспанії» КПЛ ООН відзначає, що заявники були засуджені вищою судовою інстанцією, оскільки один з обвинувачених був міністром внутрішніх справ, тому відповідно до кримінально-процесуального закону справа розглядалася палатою у кримінальних справах Верховного суду. Комітет прийняв до відома аргумент держави-учасниці про те, що засудження заявників вищим судом відбулося сумісно 3 Пактом, оскільки він має на меті забезпечення незалежності судової влади. Однак це не повинно применшувати право обвинуваченого на те, щоб його засудження і вирок були переглянуті вищою судовою інстанцією. Комітет також зазначає, що засіб правового захисту «ампаро» не може вважатися підходящим засобом згідно зі змістом п. 5 ст. 14 Пакту [8].

Аналогічно до вищевказаної ситуації порушення права на оскарження було визнане і в рішенні у справі «X. Морено проти Іспанії». Згідно з обставинами справи заявник був засуджений Верховним судом при розгляді справи в апеляційній інстанції після оскарження прокуратурою виправдувального вироку. КПЛ ООН вказав, що відсутність будь-якого права на перегляд у вищому суді обвинувального вироку, винесеного апеляційним судом, в ситуації, коли особа не була визнана винною судом першої інстанції, $\epsilon$ порушенням права на оскарження [9].

Схожі рішення приймалися і в ситуації, коли особа вперше була засуджена судом апеляційної інстанції, що не $\epsilon$ Верховним судом, після скасування виправдувального вироку, винесеного судом першої інстанції, і відповідно до національного законодавства була відсутня можливість подальшого оскарження в апеляційній чи касаційній інстанції [10].

Відносно недавно правову оцінку з боку ЄСПЛ отримало наявне в деяких державах обмеження права засудженого на оскарження вироку, винесеного за результатами угоди зі стороною обвинувачення. У рішенні у справі «Нацвлішвілі і Тогонідзе проти Грузї̈» ЄСПЛ була підтверджена правомірність такого обмеження. Європейський Суд вважає розумним обмеження здійснення права на оскарження з урахуванням угоди з обвинуваченням. Погоджуючись на операцію, особа відмовляється від свого права на ординарне оскарження [11].

Звісно ж, що укладення такого договору може розглядатися як випадок (мається на увазі відмова від права на апеляцію), який має місце при усвідомлених, добровільних діях особи до винесення щодо неї вироку, відповідно до яких особа бере на себе зобов'язання не оскаржувати такий вирок.

У практиці КПЛ ООН ситуація відмови від права на апеляцію була визнана, коли на неодноразову вимогу особи, яка раніше була суддею, кримінальну справу стосовно якої в першій інстанції було розглянуто Верховним судом, засуджений втратив можливість оскаржити вирок у вищому суді. КПЛ ООН у своєму рішенні визнав скаргу зловживанням правом на подання повідомлень.

Крім допускаючих обмежень у праві на оскарження, ще одним критерієм даного права, на нашу думку, $\epsilon$ такий критерій, як вимоги до форми розгляду справи при перегляді судом другої інстанції, які відображаються в процедурі перегляду. Безумовно, цей критерій тісно пов'язаний з попереднім, проте має і самостійне значення.

Як уже зазначалося, КПЛ ООН не пред'являє будьяких особливих вимог до процедури оскарження, в тому числі й не вимагає повного повторного розгляду справи. Звісно ж, це дозволяє зробити висновок про те, що КПЛ ООН у своїй діяльності застосовує сутнісний, а не формальний підхід.

Практика ЄСПЛ у зв'язку з цим видається дещо непослідовною. 3 одного боку, як нами вже зазначалося, ЄСПЛ досить лояльно ставиться до процедур, які обмежують право на оскарження, які були розглянуті вище, а з іншого - в рішеннях ЄСПЛ неодноразово визнавалися порушеннями положень Конвенції ситуації, коли не здійснювався повний перегляд справи, передбачений національним законодавством. Наприклад, в рішенні у справі «Екбатану (Ekbatani) проти Швеції», яка отримала широку популярність, ЄСПЛ визначив, що Апеляційний суд був покликаний розглянути як питання факту, так і права і вирішити питання про винуватість чи невинуватість заявника. Беручи до уваги систему 
шведських судів, місце і роль в ній Апеляційного суду i характер поставленого перед ним питання, ЄСПЛ дійшов висновку, що у справи не було особливих рис, що виправдовували відмову в публічному розгляді і позбавлення заявника права бути заслуханим особисто [12].

Складається ситуація, коли одні і ті ж дії судових органів різних держав можуть кваліфікуватися неоднаково. Наприклад, якщо національне законодавство взагалі не передбачає перегляд будь-якої категорії справ на фактичних підставах, то ЄСПЛ порушень Конвенції не вбачає, однак, якщо національне законодавство передбачає такий перегляд, але він не був здійснений в належному порядку, то порушення Конвенції вбачається. Таким чином, рішення ЄСПЛ у значній мірі визначаються не єдиними загальними критеріями, як рішення КПЛ ООН, а особливостями національного законодавства. Однак оцінка дій держав-відповідачів за скаргами громадян про порушення їхніх прав і свобод повинна бути однаковою і відповідною до єдиних критеріїв.

Схожа ситуація простежується і при визначенні можливості оскарження проміжних судових рішень, пов'язаних із застосуванням запобіжного заходу у вигляді взяття під варту. Зокрема, в своїх рішеннях ЄСПЛ неодноразово вказував, що, хоча він не зобов'язує створювати другий рівень юрисдикції для перевірки законності взяття під варту, держава, яка засновує таку систему, має в принципі забезпечувати ув'язненим при оскарженні ті ж гарантії, що й в суді першої інстанції [13].

Обсяг прав, які вкладаються в поняття «право на оскарження», може бути визначений, зокрема i на підставі тих порушень, які були виявлені ЄСПЛ і КПЛ ООН при розгляді скарг на порушення даного права. Основними порушеннями Конвенції, безпосередньо пов'язаними з правом на оскарження, в практиці ЄСПЛ були визнані такі.

1. Порушення права обвинуваченого особисто бути присутнім при розгляді скарги. Згідно з усталеною практикою ЄСПЛ порушенням даного права визнається ситуація, коли суд не забезпечив особисту присутність обвинуваченого або хоча б захисника, уповноваженого ним, при розгляді фактичних обставин справи, оскільки за таких умов особа втрачає можливість представити докази на підтримку своєї апеляції.

У деяких випадках порушенням Конвенції визнавалося незабезпечення судом особистої присутності обвинуваченого і в випадках, коли його інтереси були представлені захисником, але з огляду на сутність розглянутих питань справедливий розгляд апеляції без особистої присутності обвинуваченого вважається неможливим. Наприклад, у справі «М. Кук проти Австрії» ЄСПЛ зазначає: «Верховний Суд був покликаний розглянути питання про скорочення покарання щодо особи, засудженої до двадцяти років позбавлення волі, або про його посилення до довічного позбавлення волі. 3 огляду на характер основного питання, а також на можливість посилення покарання до довічного позбавлення волі справа не могла бути розглянута належним чином без отримання судом особистого враження про заявника» [14].

Дане право обвинуваченого в практиці ЄСПЛ не $\epsilon$ абсолютним. Воно пов'язане з характером тих обставин, які підлягають перегляду. Так, якщо перегляду підлягають тільки правові питання, то особиста присутність обвинуваченого за наявності адвоката не $є$ обов' язковою.
Однак у справі «Синичкин проти Росії» ЄСПЛ вказує: «Неподання заявником клопотання про участь не становить ясної і недвозначної відмови від цього права». Отже, згідно з позицією ЄСПЛ суд другої інстанції повинен з'ясувати бажання підсудного брати участь в судовому засіданні під час перегляду своєї справи.

2. Порушення права обвинуваченого на захист за допомогою призначеного адвоката. ЄСПЛ неодноразово визнавав порушенням положень Конвенції відмову суду, який здійснює перегляд справи, від надання обвинуваченому допомоги призначеним захисником [15].

Безумовно, обидва вищевказаних порушення (як порушення права обвинуваченого особисто бути присутнім при розгляді скарги, так і порушення права обвинуваченого на захист за допомогою призначеного адвоката) належать до порушення пункту «С» частини 3 статті 6 Конвенції та можуть бути класифіковані як порушення права на захист, а також як порушення принципу змагальності у справах щодо перегляду судових рішень.

3. Порушення права обвинуваченого на оскарження, яке виразилося в постановці особи в таку правову ситуацію, коли реалізація даного права спричинила б для неї істотні несприятливі наслідки.

Зокрема, така ситуація констатувалась ЄСПЛ в постанові у справі «Яковенко проти України». Відповідно до обставин справи заявника було засуджено до позбавлення волі. До вступу вироку в законну силу до нього було застосовано запобіжний захід у вигляді взяття під варту. Оскільки до винесення вироку заявник тривалий час перебував під вартою, термін його покарання завершився ще до вступу вироку в законну силу. Отже, оскарження вироку до вищої інстанції спричинило б продовження терміну перебування заявника в ув'язненні на невизначений період [16].

У практиці КПЛ ООН можна виділити такі виявлені при розгляді скарг громадян порушення права на оскарження:

- неповідомлення підсудного про судове рішення суду першої інстанції, винесене за його відсутності або в умовах, коли йому не було надано адвоката;

- ненадання належного захисника, зобов'язаного надати підстави для апеляції, в сукупності з обмеженням права підсудного на самозахист;

- неповідомлення обвинуваченому про дату апеляційного розгляду і про призначеного захисника, який раніше не брав участі в справі;

- ненадання підсудному мотивованого письмового рішення суду першої інстанції та інших документів (наприклад, протоколів судових засідань);

- неподання заявнику протягом тривалого терміну прийнятих у справі рішень в письмовому вигляді. Так, у своєму рішенні за результатами розгляду скарги «Астон Літтл проти Ямайки» КПЛ ООН відзначив таке: «Щоб ефективно користуватися правом на оскарження, засуджена особа має право отримати в розумні строки доступ до письмових рішень, належним чином обґрунтованих, у всіх випадках подачі апеляції. Оскільки апеляційний суд Ямайки протягом понад п'яти років після відхилення апеляції пана Літтла не виносив мотивованого рішення, заявник був позбавлений можливості ефективно оскаржити свій вирок в Судовому комітеті Таємної ради»;

- нерозгляд апеляції В розумні терміни, коли це пов'язано з оскарженням вироку, який перед- 
бачає смертну кару. Так, порушенням права на оскарження було визнано випадок, коли розгляд апеляції відкладався протягом восьми років;

- неналежне повідомлення заявника про результати розгляду справи в апеляційній інстанції, яке може ввести особу в оману щодо свого статусу. Так, КПЛ ООН визнав порушенням права на оскарження ситуацію, коли внаслідок неналежного повідомлення про результати апеляції засудженого до смертної кари, а також внаслідок подальших дій адміністрації в'язниці (переведення в загальну камеру) у нього виникло уявлення, що вирок щодо нього пом'якшений (заміна страти позбавленням волі) [17].

Аналіз практики КПл ООН дозволяє відзначити, що найбільш часто країнами-відповідачами щодо заяв, поданих до КПЛ ООН в зв'язку з можливим порушенням права на оскарження, виступали такі країни, як Ямайка та Тринідад i Тобаго, Іспанія. Глобальні порушення права на оскарження, пов'язані з правом на життя і справедливий суд, були констатовані КПЛ $\mathrm{OOH}$ в окремі періоди в таких державах, як Замбія, Сьєрра-Леоне [18].

Істотний інтерес становить позиція ЄСПЛ і КПЛ ООН щодо можливості і меж перегляду судових рішень у кримінальних справах після їх вступу в законну силу.

У своїх рішеннях за скаргами Брумареску проти Румунії і Рябих проти Росії ЄСПЛ визначає, що одним з основних аспектів верховенства права $\epsilon$ принцип правової визначеності (в іншому формулюванні - принцип юридичної (законної) впевненості), який, серед іншого, вимагає, щоб прийняте судами остаточне рішення не могло б бути оскаржене. Правова визначеність передбачає повагу принципу res judicata (остаточності рішення), тобто принципу неприпустимості повторного розгляду одного разу вирішеної справи. Принцип закріплює, що жодна зі сторін не може вимагати перегляду остаточного i такого, що вступило в законну силу, рішення тільки в цілях проведення повторного слухання та отримання нової постанови. Перегляд не може вважатися прихованою формою оскарження, в той час як лише можлива наявність двох точок зору з одного питання не може бути підставою для перегляду [19].

Попри те, що ці рішення пов'язані не з кримінальним, а з цивільним процесом, істотного значення для оцінки правової позиції ЄСПЛ це не має, оскільки даний принцип має універсальний характер. На підставі зазначеного положення ЄСПЛ формулює висновок, що рішення екстраординарних інстанцій (зокрема, наглядових), не обмежені ніякими термінами і спрямовані на перегляд судових рішень, не $\epsilon$ належними способами правового захисту.

Для діяльності ЄСПЛ це має суттєве значення при визначенні умов прийнятності скарги в ЄСПЛ, які передбачені ст. 35 Конвенції. Відповідно до ч. 1 даної статті ЄСПЛ може прийняти питання до розгляду тільки після того, як були вичерпані всі внутрішні засоби правового захисту згідно із загальновизнаними нормами міжнародного права і впродовж шести місяців з дати прийняття остаточного рішення у справі. Визнання екстраординарного провадження як засобу вичерпання правового захисту для дотримання критерію прийнятності породило б правову невизначеність, яка позбавила $б$ сенсу правило шестимісячного терміну звернення до Європейського Суду.
Важливо відзначити, що принцип правової визначеності не $\epsilon$ абсолютним, в тому числі і в практиці ЄСПЛ. У тому ж самому рішенні у справі «Рябих проти Росії» ЄСПЛ зазначає, що повноваження вищого суду щодо перегляду судового рішення (яке набрало законної сили) має (може) здійснюватися з метою виправлення судових помилок, неправильного відправлення правосуддя (п. 52).

Визнання абсолютного характеру принципу правової визначеності суперечило б безпосередньому змісту Конвенції. Зокрема, відповідно до ч. 2 ст. 4 Протоколу № 7 допускається повторний розгляд справи, якщо $\epsilon$ відомості про нові або нововиявлені факти чи суттєві недоліки у попередньому судовому розгляді, суттєві порушення, що вплинули на результат справи.

Крім того, з метою реалізації даних положень 19 січня 2000 р. Комітетом міністрів Ради Європи була прийнята Рекомендація № R (2000) 2, що закликає держави внести у національні правові системи інститут перегляду справ і відновлення провадження в зв'язку з рішеннями ЄСПЛ.

ЄСПЛ констатує, що можливість поновлення кримінальної справи як така прирівняна до Конвенції. Однак деякі особливі обставини справи можуть свідчити, що ця процедура може бути використана таким чином, який підриває саму сутність справедливого суду. Здійснення такого перегляду має використовуватися для досягнення максимально можливого і справедливого балансу між інтересами фізичної особи та необхідністю забезпечити ефективність системи кримінального судочинства.

Важливим аспектом даної проблеми $\epsilon$ розмежування понять «перегляд судового рішення, яке набрало законної сили» i «повторне засудження, заборонене ч. 1 ст. 4 Протоколу № 7». Відповідно до цієї статті жодна особа не повинна бути вдруге притягнена до суду або покарана в порядку кримінального провадження під юрисдикцією однієї і тієї самої держави за правопорушення, за яке ії було остаточно виправдано або засуджено відповідно до закону та кримінально-процесуального законодавства цієї держави.

У наведеній постанові у справі «Нікітін проти Росії» ЄСПЛ зазначає, що ст. 4 Протоколу № 7 проводить чітке розмежування повторного притягнення до суду і відновлення судового розгляду у виняткових обставинах. Можливість відновлення кримінальної справи за новими або нововиявленими обставинами, а також перегляду справи в зв'язку з судовими помилками в застосуванні норм матеріального та процесуального права не $\epsilon$ порушенням принципу ne bis in idem. Предметом такого розгляду $\epsilon$ те саме кримінальне обвинувачення і законність винесених раніше рішень. Якщо протест був задоволений і справа надходить на новий розгляд, то підсумком перегляду стане скасування всіх винесених раніше судами рішень і винесення нового рішення у кримінальній справі. У цьому контексті обидві процедури являють собою форми продовження попереднього провадження (п. 45-46 постанови) [20].

Висновки. Отже, вважаємо за можливе сформулювати деякі висновки про міжнародні стандарти права на оскарження, які були визначені практикою ЄСПЛ і КПЛ ООН.

Відповідно до даних міжнародних стандартів безумовне право на оскарження судових рішень у кримі- 
нальних справах має тільки засуджений. Крім цього, згідно з позицією ЄСПЛ в тому випадку, якщо національне законодавство передбачає можливість оскарження рішення про застосування запобіжного заходу у вигляді взяття під варту, дане право належить і особі, щодо якої цей запобіжний захід застосовується. Зміст і межі права на оскарження судових рішень у кримінальних справах інших учасників кримінального судочинства, в т.ч. потерпілого, визначається національним законодавством і не $\epsilon$ частиною даних міжнародних стандартів.

Державам-учасницям ЄСПЛ надає досить широкі можливості обмеження права на оскарження, встановлюючи, що підстави для перегляду визначаються національними законодавствами, а державам надається широка свобода розсуду при визначенні того, як право оскарження буде здійснюватися. В одних випадках право оскарження може обмежуватися тільки питаннями права, в інших випадках особа, яка бажає звернутися до вищого суду, має отримати дозвіл на апеляцію. Крім того, відповідно до наявних застережень в ч. 2. ст. 2 Протоколу № 7 до Конвенції в праві на оскарження можуть робитися винятки для незначних правопорушень, а також коли особу було засуджено рішенням у першій інстанції (Верховним судом) або засуджено після оскарження виправдувального вироку.

У своїй практиці КПЛ ООН дотримується іншої точки зору на допустимість подібних обмежень, вважаючи, що перегляд, який обмежується формальними або правовими аспектами засудження без будь-якого розгляду фактів, $є$ недостатнім. Крім того, Міжнародний пакт про громадянські і політичні права, на відміну від Європейської конвенції про захист прав людини i основних свобод, не містить ніяких застережень у праві на оскарження.

Яких-небудь особливих вимог до процедури оскарження КПЛ ООН не пред'являє, в тому числі й не вимагає повного повторного розгляду справи. Практика ЄСПЛ у зв'язку з цим видається дещо непослідовною. 3 одного боку, ЄСПЛ досить лояльно ставиться до вищевказаних процедур, які обмежують право на оскарження, а з іншого - в рішеннях ЄСПЛ неодноразово визнавалися порушеннями положень Конвенції ситуації, коли не здійснювався повний перегляд справи, передбачений національним законодавством.

\section{Література}

1. Головко Л.В. Соотношение уголовных преступлений и административных правонарушений в контексте концепции criminal matter (уголовной сферы). Международное правосудиe. 2013. № 1. С. 42-52.

2. П. 52-56 Judgment ECHR of case of Gurepka v. Ukraine, appl. № 61406/00. 6 September 2005. URL: http://hudoc. echr.coe.int/sites/eng/pages/search.aspx?i=001-70094.

3. Пункт 45 Замечаний общего порядка № 32 кПч $\mathrm{OOH}$ Международного пакта о гражданских и политических правах № CCPR/C/GC/32 от 23.08.2007. URL: http://tbinternet.ohchr.org/_layouts/treatybodyexternal/ Download.aspx?symbolno=CCPR\%2fC\%2fGC\%2f32\&Lang=ru.

4. Головненков П., Спица Н., Хелльманн У. Уголовнопроцессуальный кодекс Федеративной Республики Германия : научно-практический комментарий и перевод текста закона. Москва : МГЮА имени О.Е. Кутафина, 2012. 330 с.
5. Справедливое судебное разбирательство в международном праве : юридический сборник. Варшава : БДИПч ОБСЕ, 2013. 342 C.

6. Пункты 9.1-10 Соображений КПч ООН от 23 ноября 2009 г. № CCPR/C/97/D/1363/2005 по жалобе Херардо Гайосо Мартинеса (Gerardo Gayoso Martínez) против Испании. URL: http://juris.ohchr.org/Search/Details/1027.

7. Пункт 8.3 Соображений КПЧ ООН от 24 августа 2010 г. № CCPR/C/99/D/1797/2008 по жалобе Томаса Вильхельмуса Хенрикуса Меннена (Thomas Wilhelmus Henricus Mennen) против Нидерландов. URL: http://juris.ohchr.org/Search/ Details/1524.

8. Пункты 9.1-10 Соображений КПЧ ООН от 18 апреля 2008 г. № CCPR/C/92/D/1351-1352/ 2005 по жалобам Luis Hens Serena и Juan Ramón Corujo Rodríguez против Испании. URL: http://juris.ohchr.org/Search/Details/1418.

9. Пункты 7.2-8 Соображений КПЧ ООН от 11 сентября 2007 г. № CCPR/C/90/D/1381/2005 по жалобе Jaques Hachuel Moreno против Испании. URL: http://juris.ohchr.org/ Search/Details/1381.

10. Пункты 7.2-8 Соображений КПЧ ООН от 15 ноября 2006 г. № CCPR/C/88/D/1332/2004 по жалобе Juan García Sánchez and Bienvenida González Clares против Испании. URL: http://juris.ohchr.org/Search/Details/1295.

11. Пункты 96-98 Judgment ECHR of case of Natsvlishvili and Togonidze v Georgia, appl. № 9043/05, 29 April 2014. URL: http://hudoc.echr.coe.int/eng?i=001-142672.

12. Judgment ECHR of case of Ekbatani v Sweden, appl. № 10563/83, 26 May 1988. URL: http://hudoc.echr.coe.int/ rus?i=001-100704.

13. Пункт 28 Judgment ECHR of case of Navarra v France, appl. № 13190/87, 23 November 1993. URL: http://hudoc.echr.coe.int/eng?i=001-57857.

14. Пункты 40-44 Judgment ECHR of case of Cooke v. Austria, appl. № 25878/94, 8 February 2000. URL: http://hudoc.echr.coe.int/eng?i=001-58460.

15. Пункт 40 Judgment ECHR of case of Sinichkin v Russia, appl. № 20508/03, 08 April 2010. URL: http://hudoc.echr.coe.int/eng?i=001-98128.

16. Judgment ECHR of case of Yakovenko v. Ukraine, appl. № 5425/11, 4 June 2015. URL: http://hudoc.echr.coe. int/eng?i=001-156909.

17. Соображения КПЧ ООН от 18 ноября 2005 г. № CCPR/C/85/D/1132/2002 по жалобе Chisanga против Замбии. URL: http://juris.ohchr.org/Search/Details/1205.

18. Соображения КПЧ ООН от 30 июля 2001 г. № ССРR/ C/72/D/839-840-841/1998. URL: http://juris.ohchr.org/ Search/Details/925.

19. Пункты 51-52 Judgment ECHR of case of Ryabykh v Russia, appl. № 52854/99, 24 July 2003. URL: http: / / hudoc. echr.coe.int/eng?i=001-94131; п. 61-62 Judgment ECHR of case of Brumarescu v. Romania, appl. № 28342/95, 28 October 1999. URL: http://hudoc.echr.coe.int/eng?i=001-58337.

20. Пункт 10.13 Соображений КПЧ ООН от 28 марта 2006 г. № CCPR/C/86/D/1100/2002 по жалобе Юрия Бандажевского против Белоруссии. URL: http://juris.ohchr.org/ Search/Details/1248.

Качалко К. П., слухач магістратури факультету № 3 одеського державного університету внутрішніх справ

Плужнік О. I., кандидат юридичних наук, доцент, професор кафедри кримінального права та кримінології Одеського державного університету внутрішніх справ 